\title{
Kemampuan Bakteri Endofit Akar dan Ubi Kentang untuk Menekan Penyakit Busuk Lunak (Erwinia carotovora pv. carotovora) pada Ubi Kentang
}

\author{
Noor Istifadah ${ }^{*}$, Muhamad Salman Umar $^{2}$, Sudarjat $^{1}$ dan Luciana Djaya ${ }^{1}$ \\ ${ }^{1}$ Departemen Hama dan Penyakit Tumbuhan, Fakultas Pertanian, Universitas Padjadjaran \\ ${ }^{2}$ Alumnus Program Studi Agroteknologi, Fakultas Pertanian, Universitas Padjadjaran \\ *Alamat korespondensi: n.istifadah.unpad.ac.id
}

\begin{abstract}
The abilities of endophytic bacteria from potato roots and tubers to suppress soft rot disease (Erwinia carotovora pv. carotovora) in potato tuber
\end{abstract}

Soft rot disease caused by Erwinia carotovora pv. carotovora is one of limiting factors in cultivation and post harvest of potato. The eco-friendly control measure that can be developed for controlling the diseases is biological control. Microbes that are potential as biological control agents include endophytic bacteria. This paper discussed the results of study examining the potential of endophytic bacteria isolated from roots and tubers of potato to inhibit the growth of E. carotovora pv. carotovora in vitro and suppress soft rot disease in potato tuber. The results showed that among 24 isolates examined, four isolates of endophytic bacteria (one isolate from potato tuber and three isolates from potato roots) inhibited the growth of $E$. carotovora pv. carotovora in vitro with inhibition zone 3.5-6.8 mm. In the in vivo test, the isolates inhibited the soft rot disease in potato tuber by $71.5-86.4 \%$. The isolate that tended to show relatively better inhibition in vitro and in vivo was isolate from potato tuber which is $\mathrm{CK}_{3}$ (Lysinibacillus sp.)

Keywords: Biological control, Endophytic bacteria, Post-harvest, Potato, Soft rot disease

\begin{abstract}
ABSTRAK
Penyakit busuk lunak yang disebabkan bakteri Erwinia carotovora pv. carotovora, merupakan salah satu kendala dalam budidaya dan pascapanen kentang. Cara pengendalian ramah lingkungan yang dapat dikembangkan untuk menekan penyakit tersebut adalah pengendalian biologi. Kelompok mikroba yang berpotensi sebagi agens pengendali biologi adalah bakteri endofit. Artikel ini mendiskusikan potensi isolat bakteri endofit yang berasal dari ubi dan akar kentang untuk menghambat pertumbuhan bakteri E. carotovora pv. carotovora secara in vitro dan menekan perkembangan penyakit busuk lunak pada ubi kentang. Hasil percobaan menunjukkan bahwa diantara 24 isolat bakteri yang diuji, terdapat empat isolat bakteri endofit (satu isolat dari ubi kentang dan tiga isolat dari akar kentang) yang dapat menghambat pertumbuhan bakteri $E$. carotovora pv. carotovora secara in vitro dengan zona penghambatan sebesar 3,5-6,8 mm. Pada pengujian secara in vivo, isolat-isolat tersebut dapat menekan perkembangan penyakit busuk lunak pada ubi kentang sebesar $71,5-86,4 \%$. Isolat yang cenderung menunjukkan penghambatan relatif lebih baik secara in vitro dan in vivo adalah isolat bakteri endofit asal ubi kentang yaitu isolat CK $\mathrm{U}_{3}$ (Lysinibacillus sp.).
\end{abstract}

Kata Kunci: Pengendalian biologi, Bakteri endofit, Pascapanen, Kentang, Penyakit busuk basah

\section{PENDAHULUAN}

Kentang merupakan salah satu bahan pangan yang mempunyai multi fungsi baik sebagai sumber karbohidrat maupun bahan dari berbagai makanan lain termasuk sayur ataupun makanan ringan. Jawa Barat merupakan salah satu daerah sentra produksi kentang di Indonesia, baik kentang 
untuk bahan pangan maupun untuk kentang untuk bibit (Pijoto, 2004).

Salah satu kendala dalam produksi kentang baik untuk keperluan konsumsi maupun untuk bibit adalah adanya penyakit busuk basah (Erwinia carotovora $p v$. carotovora). Selain merupakan penyakit terbawa tanah yang merugikan pada pertanaman, penyakit tersebut juga merupakan penyakit pasca panen yang berkembang di penyimpanan dan juga terbawa ubi/bibit kentang (seed borne) (Elphinstone, 1987; Tsror et al., 1999).

Penyakit busuk lunak pada kentang sulit untuk dikendalikan sehingga memerlukan upaya pengendalian secara terpadu. Penggunaan pestisida untuk penyakit tular tanah sangat beresiko karena pencemaran lingkungan terutama lingkungan tanah dan juga karena dapat mendorong timbulnya resistensi patogen. Salah satu komponen pengendalian secara terpadu yang ramah lingkungan dan efeknya berkelanjutan adalah pengendalian secara biologi.

Kelompok mikroorganisme yang berpotensi sebagai agen pengendali biologi penyakit adalah bakteri endofit yaitu bakteri yang sebagian atau seluruh hidupnya ada dalam jaringan tumbuhan tanpa menimbulkan gejala penyakit (Stone et al., 2000). Walaupun ada bakteri endofit yang keberadaanya tidak berpengaruh terhadap tanaman inang atau pada beberapa kasus ada yang merupakan patogen laten, namun banyak bakteri endofit yang dapat menguntungkan tanaman inangnya (Rosenblueth \& Martínez-Romero, 2006). Bakteri endofit ada yang dapat meningkatkan pertumbuhan tanaman inangnya (Gaiero et al., 2013; Chaturvedi et al., 2016) dan juga ada yang dapat mengendalikan penyakit tanaman inangnya (Strurtz \& Nowak, 2000; Sturtz et al., 2000; Backman \& Sikora, 2008).

Kemampuan antagonistik bakteri endofit berasosiasi dengan tanaman kentang untuk mengendalikan patogen atau penyakit tanaman telah dikaji. Bakteri endofit asal perakaran tanaman kentang dilaporkan dapat menekan beberapa patogen tular tanah seperti Verticillium dahliae dan Rhizoctonia solani (Berg et al., 2005). Bakteri endofit yang diisolasi dari ubi kentang ada juga ada yang bersifat antagonstik terhadap beberapa patogen tular tanah seperti Fusarium spp. dan Phytophthora infestans secara in vitro (Sturtz et al., 1999). Bakteri endofit yang berasal dari batang kentang (Reiter et al., 2002) dan ubi kentang (Czajkowski et al., 2012) juga dilaporkan dapat menekan penyakit busuk pangkal batang (blackleg) pada kentang oleh
Erwinia carotovora var atroseptica Reiter et al. (2002) atau Dickeya sp. (Czajkowski et al., 2012). Bakteri endofit telah diisolasi dari akar dan ubi kentang dari berbagai sentra produksi kentang di Jawa Barat antara lain dari daerah Ciwidey, Pangalengan (Kabupaten Bandung), Lembang (Bandung Barat), Pasirwangi, Cisurupan (Kabupaten Garut). Artikel ini mendiskusikan hasil penelitian yang mengkaji kemampuan isolat bakteri endofit asal ubi dan akar kentang tersebut untuk menekan penyakit busuk lunak (E. carotovora $p v$. carotovora) pada ubi kentang.

\section{BAHAN DAN METODE}

\section{Uji kemampuan antagonistik bakteri endofit terhadap E. carotovora pv. carotovora secara in vitro}

Isolat bakteri endofit yang digunakan adalah isolat-isolat yang sudah diketahui tidak bersifat patogenik dan tidak menghambat pertumbuhan tanaman kentang (Istifadah dkk., 2013). Isolat yang digunakan pada pengujian secara in vitro adalah sebanyak 24 isolat. Pengujian kemampuan antagonistik isolat bakteri endofit secara in vitro dilakukan dengan metode filter paper (Dhingra \& Sinclair, 1995). Percobaan dilakukan dengan menggunakan Rancangan Acak Lengkap dengan tiga ulangan. Perlakuan yang diuji adalah isolat-isolat bakteri endofit dan kontrol. Suspensi bakteri E. carotovora pv. carotovora sebanyak $1 \mathrm{ml}$ dimasukkan ke dalam petridish kemudian $9 \mathrm{ml}$ medium Nutrient Agar dimasukkan dan dicampur dengan suspensi bakteri tersebut. Setelah dingin, potongan filter paper berdiameter $1 \mathrm{~cm}$ yang telah dicelupkan dalam suspensi bakteri diletakkan pada medium. Untuk kontrol, potongan filter paper dicelupkan pada air steril. Pengamatan dilakukan 3 dan 7 hari setelah inokulasi patogen dengan mengukur lebar zona penghambatan yang terbentuk di sekitar koloni bakteri endofit.

Uji kemampuan bakteri endofit untuk menekan penyakit busuk lunak (E. carotovora pv. carotovora) pada ubi kentang

Mengingat penyakit ini lebih banyak berkembang pada ubi kentang setelah dipanen, maka percobaan dilakukan menggunakan ubi kentang. Pada percobaan ini, isolat bakteri endofit yang digunakan adalah isolat yang pada pengujian in vitro menunjukkan zona hambat. Percobaan menggunakan Rancangan Acak Kelompok, dimana yang dianggap blok adalah kotak inkubasi ubi 
kentangnya. Perlakuan terdiri dari isolat bakteri endofit yang membentuk zona inhibition pada pengujian in vitro serta kontrol dengan jumlah ulangan masing-masing sebanyak enam ulangan.

Sebelum diberi perlakuan, ubi kentang dicuci dengan air mengalir dan dikeringkan. Setelah itu, ubi didesinfestasi dengan mengusap seluruh permukaannya dengan alkohol 70\%. Guna meyakinkan masuknya bakteri endofit ke dalam jaringan ubi serta infeksi E. carotovora pv. carotovora nantinya, maka ubi kentang diberi pelukaan dengan cara menusukkan ujung jarum steril sebanyak 3 tusukan, kemudian bagian yang dilukai ditandai (dengan membuat bulatan di sekeliling daerah luka tersebut). Inokulasi bakteri endofit pada ubi kentang dilakukan dengan merendam kentang yang telah dilukai tersebut pada suspensi bakteri endofit (kerapatan $10^{7} \mathrm{cfu} / \mathrm{ml}$ ) selama satu jam. Untuk kontrol, ubi kentang direndam dengan air steril. Agar bakteri endofit dapat mengolonisasi ubi kentang, maka ubi kentang yang telah diberi perlakuan diinkubasikan selama dua minggu dalam kotak plastik bertutup. Setiap kotak berisi 5 ubi kentang dari perlakuan yang berbeda. Inokulasi bakteri E. carotovora pv. carotovora pada ubi kentang yang telah diberi perlakuan termasuk kontrol dilakukan dengan cara meneteskan suspensi bakteri (kerapatan $10^{7} \mathrm{cfu} / \mathrm{ml}$ ) sebanyak $20 \mu \mathrm{l}$ ke bagian ubi yang telah dilukai dengan ujung jarum steril. Ubi kentang yang telah diinokulasi bakteri patogen diinkubasikan pada wadah plastik bertutup yang telah dibersihkan dengan menggunakan alkohol 70\%. Guna mempertahankan kelembaban, maka pada setiap pojok dalam kotak diletakkan kapas basah. Pengamatan dilakukan seminggu setelah inokulasi patogen. Ubi kentang dibelah dan luas bagian yang busuk dihitung.

\section{HASIL DAN PEMBAHASAN}

Kemampuan antagonistik bakteri endofit terhadap $E$. carotovora pv. carotovora secara in vitro

Diantara 24 isolat yang diuji, terdapat empat isolat (tiga isolat dari akar kentang dan satu isolat dari ubi kentang) yang membentuk zona penghambatan terhadap $E$. carotovora pv. carotovora secara in vitro. Lebar zona penghambatan yang terbentuk ternyata semakin hari semakin bertambah seiring dengan pertumbuhan koloni bakterinya. Hal ini diduga terkait dengan pembentukan metabolit sekunder yang semakin banyak. Isolat yang menunjukkan zona hambat 6,25-6,75 $\mathrm{mm}$ adalah isolat bakteri endofit dari akar kentang isolat Lembang (LB $A_{2}$ ) dan bakteri endofit dari ubi kentang isolat Cikajang, $\mathrm{CK}_{3}$ (Tabel 1).

Tabel 1. Lebar zona hambat bakteri endofit terhadap bakteri patogen $E$. carotovora pv. carotovora (7 hari setelah pelakuan).

\begin{tabular}{lc}
\multicolumn{1}{c}{ Perlakuan } & Rata-rata lebar zona hambat $(\mathrm{mm})$ \\
\hline Kontrol & $0,0 \mathrm{~b}$ \\
Isolat CK A 10 & $4,3 \mathrm{a}$ \\
Isolat PG A6 & $3,5 \mathrm{a}$ \\
Isolat LB A 2 & $6,3 \mathrm{a}$ \\
Isolat CK U 3 & $6,8 \mathrm{a}$ \\
\hline Keterangan: Huruf yang sama pada satu kolom dalam table \\
\multicolumn{2}{c}{ menunjukkan data tidak berbeda nyata dengan } \\
control berdasarkan uji Duncan 5\%.
\end{tabular}

Adanya zona hambat di sekitar koloni bakteri menunjukkan adanya mekanisme antibiosis. Isolat bakteri endofit tersebut dapat menghasilkan metabolit sekunder yang dapat terdifusi ke media dan menghambat E. carotovora pv. carotovora. Bakteri endofit banyak dilaporkan dapat menghasilkan antibiotik yang bersifat toksik terhadap jamur (antifungi) atau bakteri (antibakteri) (Tan \& Zou, 2001; Rosenblueth \& MartínezRomero, 2006; Backman \& Sikora, 2008).

\section{Kemampuan bakteri endofit untuk mengendalikan penyakit busuk (E. carotovora pv. carotovora) pada ubi kentang}

Isolat yang digunakan pada pengujian in vivo adalah empat isolat yang menunjukkan zona penghambatan pada pengujian secara in vitro. Perendaman ubi kentang pada suspensi isolat bakteri yang diuji dapat menghambat terjadinya pembusukan pada ubi kentang yang diinokulasi dengan E. carotovora pv. carotovora. Pada ubi yang diberi perlakuan bakteri endofit, walaupun tampak bekas luka namun bagian tersebut mengering dan tidak terjadi pembusukan. Pada kontrol, bagian yang dilukai dan diinokulasi patogen tampak busuk mengendap dan apabila ubi kentangnya dibelah, ubi kentang menjadi busuk berlendir yang semakin meluas (Gambar 1). Pelukaan pada ubi kentang baik akibat penanganan saat panen yang kurang hati-hati maupun luka akibat hama merupakan salah satu faktor utama pendukung terjadinya infeksi $E$. carotovora pv. carotovora pada ubi kentang di penyimpanan (Tsror et al., 1999). Namun demikian, perlakuan dengan bakteri endofit ternyata dapat 
menekan perkembangan penyakit tersebut walaupun terdapat pelukaan pada ubi kentang.

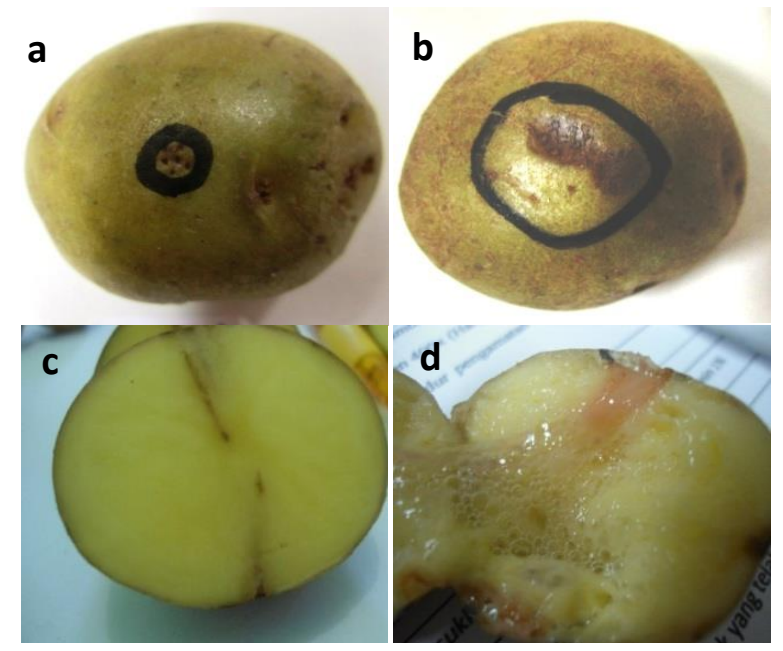

Gambar 1. Ubi kentang yang diinokulasi $E$. carotovora pv. carotovora. (a, c) Perlakuan dengan endofit. (b, d) Perlakuan tanpa endofit.

Semua isolat bakteri endofit yang diuji dapat menekan terjadinya pembusukan pada ubi kentang yang diinokulasi E. carotovora pv. carotovora dengan tingkat penghambatan sebesar 71,5-86,4\% (Tabel 2). Walaupun secara statistik tidak berbeda nyata, namun ada kecenderungan bahwa isolat bakteri endofit ubi kentang dari daerah Cikajang, Garut, $\mathrm{CK} \mathrm{U}_{3}$ (Lysinibacillus sp.) menunjukkan penghambatan terhadap $E$. carotovora pv. carotovora secara in vitro dan penyakit busuk basah pada ubi kentang yang relatif lebih baik dibandingkan dengan isolat yang lain.

Tabel 2. Pengaruh bakteri endofit terhadap penyakit busuk basah (E. carotovora $\mathrm{pv}$. carotovora) pada ubi kentang (7 hari setelah inokulasi patogen).

\begin{tabular}{lcc}
\hline Perlakuan & $\begin{array}{c}\text { Luas pembusukan } \\
(\mathrm{cm})\end{array}$ & $\begin{array}{c}\text { Persentase } \\
\text { penekanan (\%) }\end{array}$ \\
\hline Kontrol & $3,37 \mathrm{~b}$ & - \\
Isolat CK A 10 & $0,74 \mathrm{a}$ & 78,04 \\
Isolat PG A6 & $0,96 \mathrm{a}$ & 71,51 \\
Isolat LB A2 & $0,89 \mathrm{a}$ & 73,59 \\
Isolat $\mathrm{CK} \mathrm{U}_{3}$ & $0,46 \mathrm{a}$ & 86,35 \\
\hline
\end{tabular}

Keterangan: Huruf yang sama pada satu kolom menunjukkan data tidak berbeda nyata berdasarkan uji Duncan 5\%.

Isolat bakteri endofit yang menunjukkan zona penghambatan pada pengujian in vitro ternyata juga dapat menekan perkembangan penyakit busuk basah pada ubi kentang yang diinokulasi dengan $E$. carotovora pv. carotovora. Hal ini berarti bahwa salah satu mekanisme penghambatan penyakit tersebut adalah karena isolat bakteri endofit menghasilkan metabolit sekunder yang dapat menghambat perkembangan patogen. Selain itu, penghambatan perkembangan penyakit kemungkinan juga dapat terjadi karena isolat bakteri endofit yang diuji dapat meningkatkan ketahanan ubi kentang.

Kemampuan bakteri endofit untuk menginduksi ketahanan tanaman terhadap penyakit telah banyak dilaporkan (Benhamou et al., 2000; Kloepper \& Ryu, 2006). Pada penelitian lain, bakteri endofit isolat $\mathrm{CK} \mathrm{U}_{3}$ (Lysinibacillus sp.) dan PG A6 (Bacillus sp.) ternyata memang dapat menginduksi ketahanan tanaman kentang terhadap penyakit bercak kering yang disebabkan oleh Alternaria solani (Syahida, 2016). Isolat CK U3 (Lysinibacillus sp.) juga dapat menekan penyakit layu bakteri pada kentang yang disebabkan oleh Ralstonia solanacearum (Istifadah dkk., 2017, in press). Dengan demikian, isolat bakteri endofit tersebut sangat berpotensi untuk dikembangkan sebagi agens pengendali biologi berbagai penyakit pada tanaman kentang.

\section{SIMPULAN}

\section{Simpulan}

Dari hasil percobaan dapat disimpulkan bahwa:

1. Pada pengujian secara in vitro, diantara 35 isolat bakteri endofit asal ubi kentang yang diuji terdapat 4 isolat yang dapat menghambat $E$. carotovora pv carotovora dengan zona penghambatan 3,5-6,8 $\mathrm{mm}$.

2. Pada pengujian secara in vivo, isolat bakteri endofit yang diuji dapat menekan perkembangan penyakit busuk lunak pada ubi kentang sebesar 71,5-86,4\%. Isolat yang cenderung menunjukkan penghambatan relatif lebih baik secara in vitro dan in vivo adalah isolat bakteri endofit asal ubi kentang dari Cikajang yaitu isolat $\mathrm{CK} \mathrm{U}_{3}$ (Lysinibacillus sp.)

\section{Saran}

Pada penelitian ini, isolat bakteri endofit hanya diuji pada ubi kentang di penyimpanan. Kemampuan isolat bakteri endofit tersebut untuk menekan penyakit busuk basah ( $E$. carotovora pv. carotovora) yang ada pada tanaman kentang perlu dikaji lebih lanjut. 


\section{UCAPAN TERIMAKASIH}

Penelitian ini merupakan bagian dari Penelitian Unggulan Perguruan Tinggi (PUPT) Universitas Padjadjaran yang didanai oleh DP2M DIKTI. Topik ini telah dipresentasikan pada seminar Perhimpunan Fitopatologi Indonesia (PFI) Tahun 2015. Terimakasih juga disampaikan kepada Ir. Hanudin dari Balai Penelitian Tanaman Hias yang telah memberikan isolat bakteri $E$. carotovora pv. carotovora.

\section{DAFTAR PUSTAKA}

Backman, PA and RA Sikora. 2008. Endophytes: An emerging tool for biological control. Biological Control. 46:1-3.

Berg, G, A Krechel, M Ditz, RA Sikora, A Ulrich, and J Hallmann. 2005. Endophytic and ectophytic potato-associated bacterial communities differ in structure and antagonistic function against plant pathogenic fungi. FEMS Microbiology Ecology. 51:215-22.

Benhamou, N, S Gagne, QD Le, and L Dehbi. 2000. Bacterial-mediated induced resistance in cucumber: Beneficial effect of the endophytic bacterium Serratia plymuthica on the protection against infection by Pythium ultimum. Phytopathology. 90:4556.

Chaturvedi, H, V Singh, and G Gupta. 2016. Potential of bacterial endophytes as plant growth promoting factors. J Plant Pathol Microbiol, 7 (9):1-6. DOI: 10.4172/21577471.1000376. Available online at: https://www.omicsonline.org/openaccess/potential-of-bacterial-endophytes-asplant-growth-promoting-factors-2157-

7471-1000376.pdf. (accessed 10 August 2016).

Czajkowski, R, WJ de Boer, JA van Veen, and JM van der Wolf. 2012. Characterization of bacterial isolates from rotting potato tuber tissue showing antagonism to Dickeya sp. biovar 3 in vitro and in planta. Plant Pathology. 61(1):169-182.

Dhingra, OD and JB Sinclair. 1995. Basic Plant pathology Methods, $2^{\text {nd }}$ Edition. CRC Press, Boca Raton, Florida.
Elphinstone, JG. 1987. Soft Rot and Blackleg of Potato, Erwinia spp. International Potato center (CIP), Lima Peru. Available online at:

http://www.cipotato.org/library/pdfdocs/TI Ben15894.pdf. (accessed March 2014).

Gaiero, JR, CA Mccall, KA Thompson, NJ Day, AS Best, and KE Dunfield. 2013. Inside the root microbiome: Bacterial root endophytes and plant growth promotion. American Journal of Botany. 100(9):1738-1750.

Hallmann, J, A Quadt-Hallman, WF Mahaffee, and JW Kloepper. 1997. Bacterial endophytes in agricultural crops. Canadian Journal of Microbiology. 43:895-914.

Istifadah, N, D Nurma, P Suryatmana, and BN Fitriatin. 2017. The abilities of endophytic and biofertilizing bacteria and their combinations to suppress bacterial wilt disease (Ralstonia solanacearum) of chili. Proceedings of $2^{\text {nd }}$ International Conference on Sustainable Agriculture and Food Security, ICSAF (in Press).

Kloepper, JW and C-M Ryu. 2006. Bacterial endophytes as elicitors of induced systemic resistance. Pp. 33-52 in Soil Biology, Volume 9: Microbial Root Endophytes (B Schulz, C Boyle, TN Sieber, Eds.). SpringerVerlag Berlin. Heidelberg.

Pijoto. S. 2004. Penangkaran Benih Kentang. Penerbit Kanisius. Yogyakarta.

Reiter, B, U Pfeifer, H Schwab, and A Sessitsch. 2002. Response of endophytic bacterial communities in potato plants to infection with Erwinia carotovora subsp. atroseptica. Applied and Environmental Microbiology. 68(5):2261-2268.

Rosenblueth, M and E Martínez-Romero. 2006. Bacterial endophytes and their interactions with hosts. MPMI 19(8):827-837.

Sessitsch A, B Reiter, and G Berg. 2004. Endophytic bacterial communities of field-grown potato plants and their plant-growth-promoting and antagonistic abilities. Can. J. Microbiol. 50(4):239-249.

Stone, JK, CW Bacon, and JF White. 2000. An overview of endophytic microbes: endophytism defined. Pp. 3-29 in Microbial Endophytes (CW Bacon and JF White, Eds.). Marcel Dekker, Inc. New York.

Sturz, AV, BR Christie, and J Nowak. 2000 Bacterial endophytes: Potential role in developing 
sustainable systems of crop production. Syahida, KQ. 2016. Induksi Ketahanan Tanaman Critical Reviews in Plant Sciences. 19:1-30.

Sturz, AV, BR Christie, BG Matheson, WJ Arsenault, and NA Buchanan. 1999. Endophytic bacterial communities in the periderm of potato tubers and their potential to improve resistance to soil-borne plant pathogens. Plant Pathology. 48:360-369.

Sturz, AV and J Nowak. 2000. Endophytic communities of rhizobacteria and the strategies required to create yield enhancing association with crops. Applied Soil Ecology. 15:183-190.

Kentang terhadap Penyakit Bercak Kering (Alternaria solani Sor.) oleh Bakteri Endofit Asal Ubi dan Akar Kentang. Thesis Master Program Studi Agronomi. Fakultas Pertanian, Universitas Padjadjaran [Tidak dipublikasikan]

Tsror, L, M Aharon, and O Erlich. 1999. Survey of bacterial and fungal seedborne diseases in imported and domestic potato seed tubers. Phytoparasitica. 27(3):1-12.

Tan, RX and WX Zou. 2001. Endophytes: A rich source of functional metabolites. Natural Product Reports. 18:448-459. 